\title{
CHEMICAL COMPOSITION OF THE MAJHGAWAN KIMBERLITE,
} CENTRAL INDIA

\author{
By \\ S. M. Mathur \\ Mineral Exploration Corporation Limited \\ Nagpur, India
}

Majhgawan is situated about $19 \mathrm{~km}$ south-west of Panna, headquarters of the district of the same name in Madhya Pradesh. The rock occupying the diamond-bearing pipe was called 'agglomeratic tuff' by Sinor (1930) who was the first to recognize its intrusive volcanic nature. In plan the pipe is pear-shaped, its longer axis is about 500 metres and at its widest it is about 350 metres across. It is surrounded by the Dhandraul (Kaimur) Quartzite of the Vindhyan System (Mathur, 1962; Mathur and Singh, 1963).

On the basis of petrological studies Mathur and Singh (1971) considered it a kimberlite. Olivine is the most abundant constituent of the pipe rock, and is serpentinised to an extreme degree. Plilogopite, chlorite, carbonate minerals, magnetite, ilmenite, haematite, leucoxene, iddingsite, rutile, perovskite, and rarely garnet, are the other constituents of the pipe rock, besides diamond. The top section of the pipe rock is traversed by abundant calcite veinlets, which decrease with depth. In an underground drive at 100 metres depth, the rock is free of calcite veinlets.

The chemical analyses of the Majh gawan samples resemble those of kimberlites from South Africa (Wagner, 1914; Washington, 1917; and Williams, 1932) and Siberia (Burov and Sobolev, 1957). Samples of kimberlite obtained from the Majhgawan mine from the pit on the surface and from the drive give somewhat variable chemical analyses, depending mainly upon the amount of calcite veinlets present and on the degree of weathering.

Silica in the samples of the Majhgawan kimberlite obtained from the deeper levels of the pipe is roughly 37 to 40 percent, which is more akin to the South African kimberlites where the silica percentage ranges from 38 to almost 47 percent, but is higher than the Siberian kimberlites where it varies between 25 and 30 percent. Magnesia in the Majhgawan rock is generally between 14 and 16 percent in the upper parts of the pipe, but in the sample from the drive 24 percent has been recorded. On the whole this is lower than in the typical kimberlites from South Africa and Siberia where magnesia is 22 to 32 percent; it is more like melilite basalt. Titania, on the other hand, is significantly higher in the Majhgawan samples, as it ranges between 4 and 7 percent; in the kimberlite samples from other parts of the world it rarely exceeds 3 percent. Both ferric and ferrous iron, alumina and other oxides of the samples from the Majhgawan pipe are similar in percentage to the typical kimberlites from many parts of the world. Due to the profusion of calcite veins in the upper part of the Majhgawan pipe rock, the lime percentage recorded is 15 to 18 , and with the increase in depth it becomes lower as the incidence of the calcite veinlets decreases; ultimately in the drive at the 100-metre depth, where there is hardly any visible calcite, the amount of lime drops to less than 2 percent. Lime is also highly variable in the South African and Siberian kimberlites. 


\section{References}

Burov, A.P. and Sobolev, V.S. (Ed.), 1957. - "Almazi Sibiri" (Russian). Moscow: Scientific and Technical Publishing House, pp. 1-158.

Mathur, S.M., 1957. - Geology of the Panna diamond deposits. Rec.Geol. Surv. India, Vol. 87, pp. 787-816.

Mathur, S.M. and Singh, H.N., 1963. - Geology and sampling of the Majhgawan diamond deposit, Panna district, Madhya Pradesh. Bull. Geol. Surv India, Sr A, No 21, pp. 1-59.

-.-., 1971. - Petrology of the Majhgawan pipe rock. "Diamond", Misc. Pub. Geol. Surv. India, No. 19, pp. 78-85.

Sinor, K.P., 1930. - "The Diamond Mines of Panna State in Central India". Bombay: Times of India Press, pp. 1-189.

Wagner, P.A., 1914. - "The Diamond Fields of Southern Africa" . Johannesburg: Transvaal Leader, pp. 1-347.

Washington, H.S. 1917. - Chemical Analyses of Igneous Rocks Published from 1884 to 1913. U.S.G.S. Prof. Paper 99, pp. 1-1201.

Williams, A.F., 1932. - "The Genesis of the Diamond", Vol. 1, London: Everest Benn Ltd., pp. 1-352. 